\title{
Investigating the Impact of Merger \& Acquisition on Post Merger Financial Performance (Relative \& Absolute) of Companies (Evidence from Non-Financial Sector of Pakistan)
}

\author{
Khurram Ashfaq \\ Hafiz haroon ashfaq street Muslim school mohallah bhindran aroop Tehsil \& District Gujranwala Pakistan
}

\begin{abstract}
This paper aims to study the impact of merger \& acquisition activity on post merger financial performance (absolute \& relative) of companies engaged in the non-financial sector of Pakistan. There are total 16 companies selected which were engaged in the merger \& acquisition during the period 2000-2009 and which were also listed on the Karachi stock exchange. Both absolute \& relative financial performance was used to analyze the impact of merger \& acquisition. Three ratios e.g. return on equity (ROE), return on assets (ROA) and earnings per share (EPS) were used to measure the post merger financial performance. The data regarding these ratios were obtained from the annual reports of acquiring companies. While to measure absolute performance, a short type questionnaire was adapted which measures the absolute performance of acquiring companies. At initial level, descriptive statistics was used to analyze the financial performance following merger. At the second level, paired sample $t$ test was used to analyze whether relative performance was improved following merger \& acquisition. The results indicate that absolute performance on average was deteriorated following merger \& acquisition. The results of paired sample $t$ test also indicate that relative performance was also deteriorated following merger at significant level.
\end{abstract}

Keywords: Merger \& acquisition, absolute \& relative performance, financial sector, Pakistan

\section{Introduction:}

The merger \& acquisition (M \& A) activity is frequently adopted by the organization around the globe to achieve growth. The rationale behind this activity is the achievement of organization strategic objectives. Sometime it is also referred to as pooling of interest by two business entities which results in common ownership of the combined business. Alternatively company may adopt organic growth strategy to achieve its strategic objectives but it is rather more time consuming in the competitive environment. So the choice regarding the achievement of growth through acquisition or organic growth depends upon the economic environment and other factors which need to be carefully considered by the management during the selection phase. Each of the choice has its own merits and demerits in a specific situation.

The merger \& acquisition activity in Pakistan has become intensified after 2000 as a result of free trade policies promoted by the world trade organization (WTO). Beside this, the geographical agreements in area of Asian countries had also contributed towards the increase of volume of foreign direct investment and foreign portfolio investment. As a result of this, competition had become intensified which forced the national companies to consolidate their operations to achieve efficiency and maintain their market share in the presence of international competitor. The deregulation and relaxation by the regulatory authorities particularly in the service sector has motivated the companies to merge and gain competitive advantage. In addition to this, minimum capital requirement declared by the State Bank and taxation issues has forced the banks to merge. Thus the wave of merger \& acquisition in the Asian sector had gone to rise in the late 2000. Thus the merger \& acquisition activity is undertaken in the non-financial sector of Pakistan to achieve strategic objectives. The merger taken place in the textile sector are undertaken to achieve economies of scale, reduce central administration costs and managing taxation issues. The mergers in the pharmaceutical industry are taken place to reduce competition, research \& development costs. Likewise the merger in the cement sectors are also undertaken to achieve strategic objectives. Hence it can be argued that merger \& acquisition activity will provide opportunity to the merged business to achieve economies of scale in operations (Ravenscraft \& Scherer, 1987). So considering this, an attempt is made in this paper to find whether the post merger financial performance of all companies engaged in the non-financial sector was improved following the merger event. For this purpose, all those financial companies (including cement companies, textile \& pharmaceutical companies) were selected which were involved in the merger \& acquisition transaction during the period from 2000-2009.

\section{Literature review:}

The competition among the small and large companies has become intensified as a result of globalization of businesses around the globe. The merger and acquisition is one of the most important activities in the current business world which is frequently adopted by organizations for achieving objectives such as competing in the market, growth and sustain their business. The way these objectives would be realized through merger and 
acquisitions will depend upon factors such as type of merger, situation under which merger take place and other situation specific factors. Most of the time, mergers and acquisitions are used synonymously but there are certain points of differences which help to determine whether a particular activity is merger or acquisition.

Merger is defined as an activity in which two or more corporations are combined to form a completely new entity through losing their separate legal entities for achieving common objectives. The owners of combined corporations will become the joint owners of the new entity (Sudarsanam, 2003). The term consolidation is also used to refer the situation of merger (Gaughan, 2010). While on the other hand, in case of acquisition, one entity purchases the controlling ownership stake in another enterprise while retaining their separate legal entities. In such case, acquiring entity will be known as parent company and investee as subsidiary company (Chen \& Findlay, 2003). All the strategic decisions of the investee company are to be made by the acquiring company. If the acquiring company does not purchases all the shares of the investee company, then those minority shareholders are known as technically non-controlling interest. But if all the assets of the investee company are purchased, then there will be no issue of minority interest (Jaffe \& Randolph Westerfield, 2004). In merger \& acquisition scenario, both are often used interchangeably. As mentioned above that there are clear points of legal differences between merger \& acquisition. However despite these differences, the two words are used in the same sense. On international level, the merger \& acquisition activity is concerned with the buying \& selling of the company. The term includes all types of classical mergers \& acquisition, management buyouts, management buy-ins, minority equity purchases, spin offs and joint ventures. From strategic point of view, strategic alliance may also be considered as an alternative to acquisitions.

\subsection{Types of merger $\&$ acquisition:}

The objectives of the merger depend on its types i.e. horizontal, vertical or conglomerate. Each of these types has a different scenario. Horizontal combinations are meant for the combination of two or more different business units, doing similar business under one management also known as parallel combination (irshad, 2005). This type of combination results in elimination of competition, helps in regulate the market and price of the product (Green, 1990). However Lipczynski and Wilson (2004) claim that horizontal merger also results in achieving efficiency and economies of scale. For example in UK, the takeover of RHM by Premier food will make the Premier food largest food producer and thus will result in reduction of competition. The merger of Glaxo with Welcome and Lloyds TSB and HBOS in UK is also an example of horizontal combination. Similarly the purchase of Safe ways by William Morrison in the UK in 2006 reduced the number of supermarket chains and as such the level of competition in this market. In Pakistan, most of the merger \& acquisition are of horizontal nature such as the Merger of My bank Limited with and into Summit Bank Limited in 2011 and Merger of M/s. Pirkoh Gas Company (Private) Limited with and into M/s. Oil \& Gas Development Company Limited in 2008. Since this type of merger results in the elimination of competition and provide opportunity to the companies to create monopoly, so there are strict laws and rules being enforced by government of every country to promote fair competition in the market and thus avoiding monopoly. For example, in the UK, the acquisition of quoted companies is circumscribed by the City Code on Takeovers and Mergers. The Office of Fair Trading (OFT) will review the monopoly aspect of acquisition and refer the matter to the competition commission under the fair trading act if the OFT thinks that this acquisition is against the public policy. As a rule of thumb, only that acquisition will be investigated by competition commission if it results in the combined entity acquiring $25 \%$ or more of market share. Likewise, in Pakistan Office of Fair Trading is also established under the supervision of competition commission of Pakistan which regulated the merger \& acquisition in Pakistan.

Vertical merger takes place when various departments of large industrial units combine together under single management. Under this arrangement, the constituent units link up all the stages of production from purchasing of raw material to its finishing (irshad, 2005). This type of merger provides the benefits regarding secure supply of raw material, reduction in inventory costs and waste (Babu, 2005). Beside this vertical merger also results in elimination of distributor's cost because both are part of the same entity. In Pakistan, Merger of M/s. Anwar Cotton Mills (Private) Limited and M/s. Aslam Industries Limited with and into M/s. ACRO Textile Mills Limited is an example of vertical integration. In case of conglomerate combination, those corporations are combined which are unrelated in terms of both value chain process and nature of business. One claim often put forward for this type of combination is the diversification of business risk by having a portfolio of unrelated businesses (Coyle, 2000). The true value created by conglomerate combination for shareholders is questionable as portfolio theory also claims that shareholders are wise enough that they can develop diversified portfolio. Research by Morck, Shleifer, and Vishny (2012) concludes that this type of combination does not lead to positive relation with shareholder wealth rather with management's objectives. However Gorton and Rosen (1997) show that conglomerate merger may be advantageous during the period of industry consolidation. They claim that even without the cost efficiency, wealth can be maximized through increasing diversification. As far as the mergers of banks are concerned, they are undertaken for diversification purposes. Again there is no evidence of this incremental diversification and shareholder wealth (Demsetz \& Strahan, 1997); Gorton and Rosen (1997). The reason cited for this failure is the unforeseen costs associated with the merger. On the basis of 
relationship with the target company, merger and acquisition transactions can be classified as hostile or friendly takeover. A takeover is defined as hostile if the target company's management does not agree to bidder's company offer because of low bid's price or when target company management does not want to lose the job. In such case, the bidder's company makes direct contact with the target's company shareholders. On the other hand, if there is consensus between target company and bidder company's management regarding the bid price, it is claimed that friendly takeover take place (Chen \& Findlay, 2003). In addition to this, merger \& acquisition can also be classified as domestic or cross border on the basis of area. Cross border merger refers to the situation in which both target and bidding firms belong to the different countries or economies while in case of domestic merger, both firms originate from one country.

The academic literature on merger \& acquisition supports the view that mostly this activity is undertaken with a view to achieve synergy either through revenue synergy or cost synergy (Weston, Mitchell, \& Mulherin, 2004). The research on merger \& acquisition performance found three reasons related to the success or failure of merger $\&$ acquisition. A successful merger \& acquisition must have well conceived strategy behind the selection of target's company, well defined strategy of integrating the target \& bidding company and considering the drawbacks of paying too high premium (Jarillo, 2003). The frequency, volume and size of merger \& acquisition have increased to a great extent in the last decade which has become the area of study for many groups of researchers. These groups of researcher have studied the subject of merger from a different perspective.

A study by Rhoades (1993) was conducted to analyze the impact of merger \& acquisition on efficiency and profitability in banking industry. The total 33 domestic and cross border bank to bank mergers were considered for the study. The outcome of the study was that domestic mergers result in achieving cost efficiency but little improvement in profitability. However the study implies that cross border relation does not result in efficiency but little improvement in profitability. Yeh and Hoshino (2000) conducted study in Taiwan with an attempt to investigate the impact of merger on shareholder's wealth and firm performance of merged firms. The accounting based and stock return data was used to measure the impact of merger. The sample consists of 20 firms which were merged during the period of 1987-1992. The industry adjusted return on equity and return on assets were found to be decreased as compared to the premerger period. Tse and Soufani (2001) also conducted study to analyze the impact of economic conditions on achieving desired targets of merger \& acquisition. The sample of 124 merger \& acquisition transactions was selected covering the period 1990 to 1996 . The period of 1990-1993 was considered as low merger activity era which is a tough period while period of 1994-1996 was considered as high merger activity era. The sample of 124 transactions was divided into two categories 59 transactions having been related to high merger activity era and 65 transactions being related to low merger activity era. The event study methodology was used to calculate cumulative abnormal return for both eras. The study proved that economic conditions have an impact on the outcome of merger \& acquisition e.g. merger transactions in high merger activity era produced positive returns while negative returns were produced in low merger activity era. In Australian environment, Sharma and Ho (2002) analyzed the impact of merger \& acquisition on operating performance of companies. The period covered by the study was from 1986-1991 and considered 36 acquisitions during this period. However the study failed to conclude that merger \& acquisition improve operating performance of combined firms in Australian market. Hyde (2002) also conducted similar study in Australian petroleum industry to consider the impact of merger \& acquisition on the efficiency improvement and market power enhancement. However Hyde concluded that no merger results in enhancement of efficiency and market power. In Malaysian economy, Sufian (2004) investigated the impact of merger in banking industry. The efficiency effects of merger were considered for the post-merger period. The study concluded that overall efficiency was improved in all banks subject to merger except some large banks which faced certain inefficiencies of large scale.

In Egypt, study was conducted to analyze the performance of merged banks following the success of banking reforms in strengthening and consolidating this sector. Their conclusion of the study was that bank merger help to improve the significantly the profitability and minor improvement in credit risk position (Badreldin \& Kalhoefer, 2009). The effect of merger on performance was investigated by Mishra and Chandra (2010) during the period from 1964-1975 considering the Japanese manufacturing industry merger. The author concluded that merger activity helped in the improvement of performance in manufacturing industry (Ikeda \& Doi, 1983). As far as the Indian economy is concerned, a number of studies are conducted to analyze the impact of horizontal and conglomerate merger on financial and operating performance of companies. Kumar and Bansal (2008) conducted study to explore the impact of merger on company's performance. The different ratios were used to measure the performance of company. The study concluded that merger result in the maximization of shareholder's wealth through achieving synergy by reduction in cost, competition, diversification etc. whereas, Kumar and Bansal (2008) also conducted study to analyze the impact of conglomerate merger \& acquisition on operating performance of companies using financial ratios. All the mergers from 1991-2003 were considered for this study. The outcome of the study was that conglomerate mergers fail to improve operating performance. Mishra and Chandra (2010) tried to find the answer regarding whether merger in Indian pharmaceutical industry 
resulted in improvement of firm's performance. The results were that mergers failed to improve the firm's performance following merger.

As far as the Canadian economy is concerned, Andre, Kooli, and L'her (2004) attempted to analyze the long run performance of mergers in Canada and determinants of post- acquisition abnormal performance. The study's sample consists of 267 mergers covering the period from 1980-2000. The factors such as method of payment, book to market value of bidder, cross border deals were investigated to determine their impact on the success or failure of merger. The outcome of the study was that Canadian's bidder significantly underperform following post acquisition period. As far as the factors of merger success or failure are concerned, study found that method of payment has a significant impact e.g. in case, the price is settled through cash, the firms perform significantly better as compared to stock financed mergers (Andre et al., 2004). In terms of cross border merger, the companies underperform as compared to domestic mergers. However the drawback of the study was that post merger performance was not compared with the benchmark. So the negative abnormal return could be due to the industry conditions. (Yook) conducted similar study in 2004 after covering the drawback present in the study of Andre et al regarding the calculation of post merger performance as compared to benchmark. Economic value added (EVA) was calculated to measure the pre and post merger performance relative to the industry average. The period covered by the study was from 1989 to 1994 considering 75 largest acquisitions in the United States. The finding of the study was that performance was deteriorated following the merger \& acquisition. However the study failed to find any relationship between industries adjusted economic value added (EVA) and types of acquisition, method of payment and business similarity. The drawback of the study was that calculation of economic value added (EVA) is a difficult process and has a dispute regarding its calculation.

Raghavendra Rau and Vermaelen (1998) conducted comparative study regarding the success or failure of merger and tender offer by taking into account the effect of firm size, low book to market value and payment method. The sample covered by the study consists of 3169 mergers and 348 tender offers. The outcome of the study was that after adjusting for firm's size and book to market ratio, the bidding company's performance was deteriorated in merger while significantly improved in case of tender offer. The possible reasons for underperformance were the extrapolation of past performance of the target's firm and hence approve the acquisition. However the study failed to interpret the effect of method of payment as long run return are negatively related with share financed acquisitions and positive with cash financed acquisitions.

In Pakistan, Kouser and Saba (2011) attempted to find the effect of merger on profitability of commercial banks which faced merger during the period from 1999-2010. The accounting ratios were used to measure the performance of merged banks. The three years pre and post merger ratios were used and paired sample t-test method was used. The study found that the operating financial performance of all merged banks has declined later. Another study by Usman, Khan, Wajid, and Malik () was conducted to analyzed the financial performance of textile firms merged during the period from 2001 to 2005 . The paired sample t-test was used to measure the performance of merged firms. The finding of the study was that performance was insignificantly improved following the merger event. While Kemal (2011) conducted study to analyze whether the financial performance of merged banks was improved following merger using case study. The bank which was the subject of the study include Royal bank of Scotland (RBS). Four years accounting ratios were used to measure the performance of merged banks covering the period from 2006-2009. The author found that merger fails to improve the performance of banks. As far as event study methodology is concerned, Mahmood, Aamir, Hussain, and Sohail (2012) attempted to find whether the performance was improved using change in share price following the announcement of merger. The sample covered the eight companies which faced the merger during the period from 2000-2002. The outcome of the study was that five companies have faced positive change in share price following merger announcement and two being negative. While one company is not affected by merger announcement as no change in share price has taken place.

\section{Theoretical framework \& Hypothesis development:}

The above literature on merger $\&$ acquisition supports the view that market for corporate takeover is undertaken to achieve a number of objectives including to achieve operational efficiency or financial improvement through synergy either in the form of revenue, cost or financial synergy or through disciplining target's company management. The most frequently cited objective for merger \& acquisition is to achieve synergy through combination of the operation of both target and acquiring company. The methods through which achievement of objective can be checked out may include use of event studies or financial ratios. As supported by the literature review, a number of studies are conducted in different countries to analyze the post effect of merger \& acquisition on financial performance of target and acquiring companies. The results are mixed one. With respect to non-financial sector in Pakistan, only one study is conducted to analyze the effect of merger \& acquisition on post merger performance of textile firms which were selected on purposive basis. Considering this limitation, in this research paper, all the non-financial sector companies are selected which were involved in the merger \& acquisition during the period covering 2000-2009. So this analysis will diagnose the effects of merger \& 
acquisition on manufacturing sector of Pakistan and also help to make comparison of post merger performance of different sectors. These include cement companies, textile \& pharmaceutical companies. Three financial ratios were selected to measure the post merger performance of financial sector companies e.g. return on equity (ROE), return on assets (ROA) and earnings per share (EPS). Based on the above discussion, the following hypothesis was developed:

H1: Merger \& acquisition in non-financial sector has significantly improved the return on equity of acquiring firms.

H2: Merger \& acquisition in non-financial sector has significantly improved the return on assets of acquiring firms.

H3: Merger \& acquisition in non-financial sector has significantly improved the earnings per share of acquiring firms.

H4: Merger \& acquisition in cement sector has significantly improved the return on equity of acquiring firms.

H5: Merger \& acquisition in cement sector has significantly improved the return on assets of acquiring firms. H6: Merger \& acquisition in cement sector has significantly improved the earnings per share of acquiring firms. H7: Merger \& acquisition in textile sector has significantly improved the return on equity of acquiring firms. H8: Merger \& acquisition in textile sector has significantly improved the return on assets of acquiring firms. H9: Merger \& acquisition in textile sector has significantly improved the earnings per share of acquiring firms. H10: Merger \& acquisition in pharmaceutical sector has significantly improved the return on equity of acquiring firms.

H11: Merger \& acquisition in pharmaceutical sector has significantly improved the return on assets of acquiring firms.

H12: Merger \& acquisition in pharmaceutical sector has significantly improved the earnings per share of acquiring firms.

\section{Research Design \& Methodology:}

This study uses the quantitative research design as post merger performance of acquiring companies is measured with the help of three financial ratios (return on equity, return on assets and earnings per share). This section considers the description about variables used in the study, sample used, data collection method used and analysis tools used.

\subsection{Variables of the study:}

In this study, three variables are used to measure the relative post merger performance of acquiring companies e.g. return on equity (ROE), return on assets (ROA) and earnings per share (EPS). The return on equity measures the return which is available to the ordinary shareholders after paying dividend to the preference shareholders. The return on assets measures the efficiency with which the acquiring companies utilize its assets to generate profits. While earnings per share measure the earnings which the acquiring company generates per share for its ordinary shareholders. While for measuring absolute performance, synergy realization variable is chosen which is measured by a combination of questions related to this constructs.

\subsection{Sample of the study:}

The sampling method used in this study is purposive as it will fulfill our objective. As our objective is to analyze the impact of merger \& acquisition on post merger performance in non-financial sector of Pakistan economy thus non-financial sector companies engaged in the merger \& acquisition during the period covering 2000-2009 were selected. There are total of 16 acquisitions selected as sample in this study. The details regarding these acquisitions are given in the tables below.

4.3. Data collection methods:

The secondary and primary sources both are used in this study as a method for data collection. The sources used for collecting data on financial ratios is the use of annual reports of acquiring companies, Karachi stock exchange (KSE) websites, websites of acquiring companies and financial statement analysis issued by the state bank of Pakistan (SBP). Beside this for measuring the absolute performance of acquiring companies, we design eight questions on synergy realization using five point likert scales. This will measure the extent to which the acquiring company benefited from the merger \& acquisition in absolute sense. The questionnaire on measurement of synergy realization is given in the appendices section.

4.4. Data analysis tool used:

This research study is meant for analyzing the relative \& absolute post merger performance of acquiring companies using three financial ratios. So as a first step, descriptive statistics is used to analyze the trend in all these three financial ratios with the help of diagram. In addition to this descriptive statistics is used to show the absolute performance of the acquiring companies as a result of merger $\&$ acquisition. As a second tool, paired sample t-test is used to determine whether the selected financial performance indicators are significantly improved following merger \& acquisition. So considering the above statements, following analysis will be performed: 
- Descriptive statistics for relative performance of before and after merger.

- Descriptive statistics for absolute performance following merger \& acquisition.

- Paired sample t-test to determine whether relative performance significantly improved following merger \& acquisition.

\section{Research conclusions \& findings:}

For descriptive statistics of return on equity, return on assets \& earnings per share, there is significant decrease as compared to the pre merger period. In the second step, absolute performance of acquiring companies is measured using eight questions which is measured using five point likert scale. The representative of each acquiring company is selected to get their response on this absolute performance. The short type questionnaire for measurement of absolute performance is given in the appendices. Test of reliability is performed to ensure that whether the constructs accurately measure what it is supposed to measure. The cronbach's alpha is used to measure the reliability of synergy realization construct and the value of 0.710 shows sufficient reliability. Convergent validity is concerned with the degree to which the measures of constructs that theoretically should be related in fact correspond. The purpose can be fulfilled by means of correlation measures (Bollen, 1989). It is a construct which is related with testing the relationship between two measures within the same constructs. A high degree of convergent validity means that two measures of the same construct are highly related. The result of the covergent validity shows that all the dimensions of synergy realization are highly correlated. The table on absolute performance shows that each company in the non-financial sector has not performed well and realized their stated objective in terms of synergy realization. As out of total of 50 points, on average all the companies have not achieved more than $75 \%$ points. Similarly on average mean points related to synergy realization are 31 , so this also interprets the same results as stated above. So on the basis of these results, it can be inferred that absolute performance following merger has not been significantly improved.

The relative performance is analyzed with the help of paired sample t-test. The results of paired sample $t$ test are analyzed into non-financial sector, cement sector and textile sector. The above table of paired sample statistics shows that there are total 16 bidding companies under the financial sector. Beside this mean pre merger and post merger financial ratios are shown in the table of paired sample statistics. Likewise the paired sample correlation table shows the value of correlation which may be used while calculating paired sample results manually. The table of paired sample tests shows that all the financial ratios (return on equity, return on assets and earnings per share) in respect of non financial sector have been deteriorated significantly following merger except earnings per share where p-value is $42.5 \%$ i.e. greater than alpha. However in case of return on equity and return on assets, p-values are $1.9 \%$ and $2.9 \%$ respectively. The results of paired sample $t$ test in respect of cement sector match with the results of textile sector. Likewise the textile sector, financial performance in respect of all the financial ratios (return on equity, return on assets and earnings per share) has been deteriorated but the effect of deterioration is insignificant one. These results indicate that non-financial sectors companies have not performed well but at an insignificant level. In respect of pharmaceutical merger $\&$ acquisition, the return on equity has been significantly improved following merger while return on assets improved at insignificant level. However in respect of earnings per share, there is deterioration at an insignificant level. This implies that there are some factors which are not carefully considered by the non-financial sector companies following the merger. There may be poor execution of the merger process by the acquiring companies, human element poorly managed resulting in higher turnover of the employees, lack of acquisition experience.

\section{Conclusions \& Recommendations:}

The basic purpose of this study was to determine whether the post merger performance (absolute \& relative) has been improved as a result of merger event. All the acquiring companies have the basic object that post merger performance will be improved following merger transaction. Previous studies have taken into account only relative post merger performance only for determining whether the merger decision has improved the financial performance of the acquiring company. Relative post merger performance is determined by taking the difference of post merger performance from pre merger performance. The relative post merger performance method may be influenced from external factors which are not subject to acquiring company control. Considering this limitation in the previous study, this study aims to measure the post merger performance from two perspectives i.e. absolute performance \& relative performance. Absolute performance is measured by considering the synergy realization and relative performance by using the accounting ratios. Synergy realization takes into account the absolute savings resulting from the merger while relative performance measures the overall change in financial performance as a result of merger.

The results of this study are that absolute \& relative financial performance has been deteriorated following the merger event. The results of this study match with the results of study by Yeh and Hoshino (2000) in Taiwan which also concluded that return on equity \& return on assets were decreased as compared to pre merger period. Likewise, these results also match with the study undertaken under Australian environment by Sharma and Ho 
(2002). Hyde (2002) also conducted similar study in Australian petroleum industry to consider the impact of merger \& acquisition on the efficiency improvement and market power enhancement and similar findings were made. In Canadian environment, Andre, Kooli, and L'her (2004) attempted to analyze the long run performance of mergers in Canada and also concluded that post merger performance of Canadian bidders was significantly deteriorated following the acquisition period. In Indian environment, Mishra and Chandra (2010) tried to find the answer regarding whether merger in Indian pharmaceutical industry resulted in improvement of firm's performance. The results were similar that mergers failed to improve the firm's performance following merger. These finding implies that objectives set at the time of merger \& acquisition are not realized by the financial sector companies of Pakistan. So there is need by the non-financial sector companies to consider these results to understand what are the factors which are overlooked by them either at the time of merger or following the merger event. This element sets the directions for future research which can be undertaken to determine the most significant factors which are crucial for merger \& acquisition success. Beside this, on the basis of this study, comparative analysis of post merger performance (absolute \& relative) of financial \& non-financial sector can be made.

\section{Limitations of the research:}

The limitation of this study is that it takes into account only the non-financial sector companies which include textile, pharmaceutical \& cement sector companies. It also does not identify the main factors which set the direction for merger \& acquisition success or failure.

\section{Table 1: sample of companies}

\begin{tabular}{|l|l|c|l|}
\hline Sr. no. & \multicolumn{1}{|c|}{ Name of acquiring company } & Year of merger & \multicolumn{1}{|c|}{ Nature of business } \\
\hline 1 & Exide pak limited & 2009 & Automobile \\
\hline 2 & Zeal pak cement limited & 2008 & Cement \\
\hline 3 & Dewan cement limited & 2007 & Cement \\
\hline 4 & Pak Suzuki company limited & 2007 & automobile \\
\hline 5 & Thal limited & 2006 & Textile \\
\hline 6 & Nishat chunian limited & 2005 & Textile \\
\hline 7 & Kohinoor weaving mills limited & 2004 & Textile \\
\hline 8 & Pel company & 2003 & Electronics \\
\hline 9 & Ibrahim fibre & 2002 & Textile \\
\hline 10 & Abbot laboratories limited & 2002 & Pharmaceutical \\
\hline 11 & Glaxo welcome Pakistan limited & 2002 & Pharmaceutical \\
\hline 12 & Kohinoor textile mills limited & 2002 & Textile \\
\hline 13 & Nagina cotton mills limited & 2002 & Textile \\
\hline 14 & Dewan salman fibres & 2001 & Textile \\
\hline 15 & Kohinoor textile mills limited & 2001 & Textile \\
\hline 16 & DG khan cement limited & 2000 & Cement \\
\hline
\end{tabular}

Table 2: descriptive statistics for financial ratios

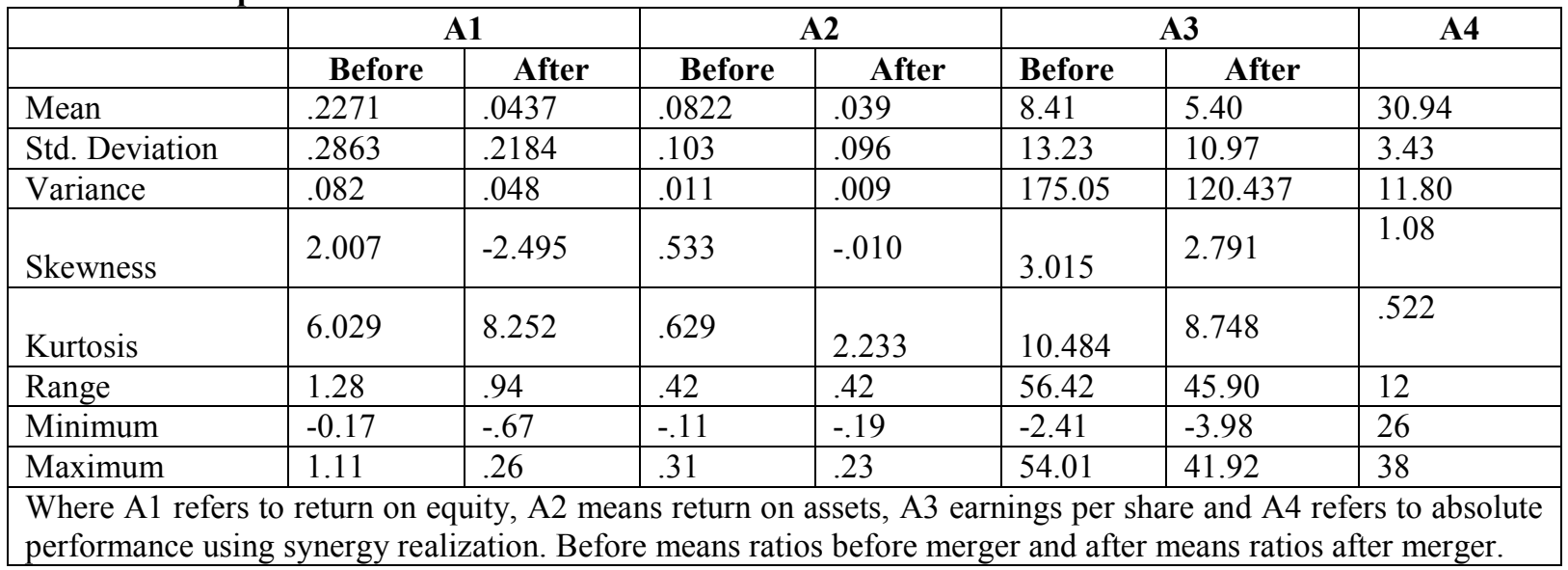


Figure 1: descriptive statistics for return on equity

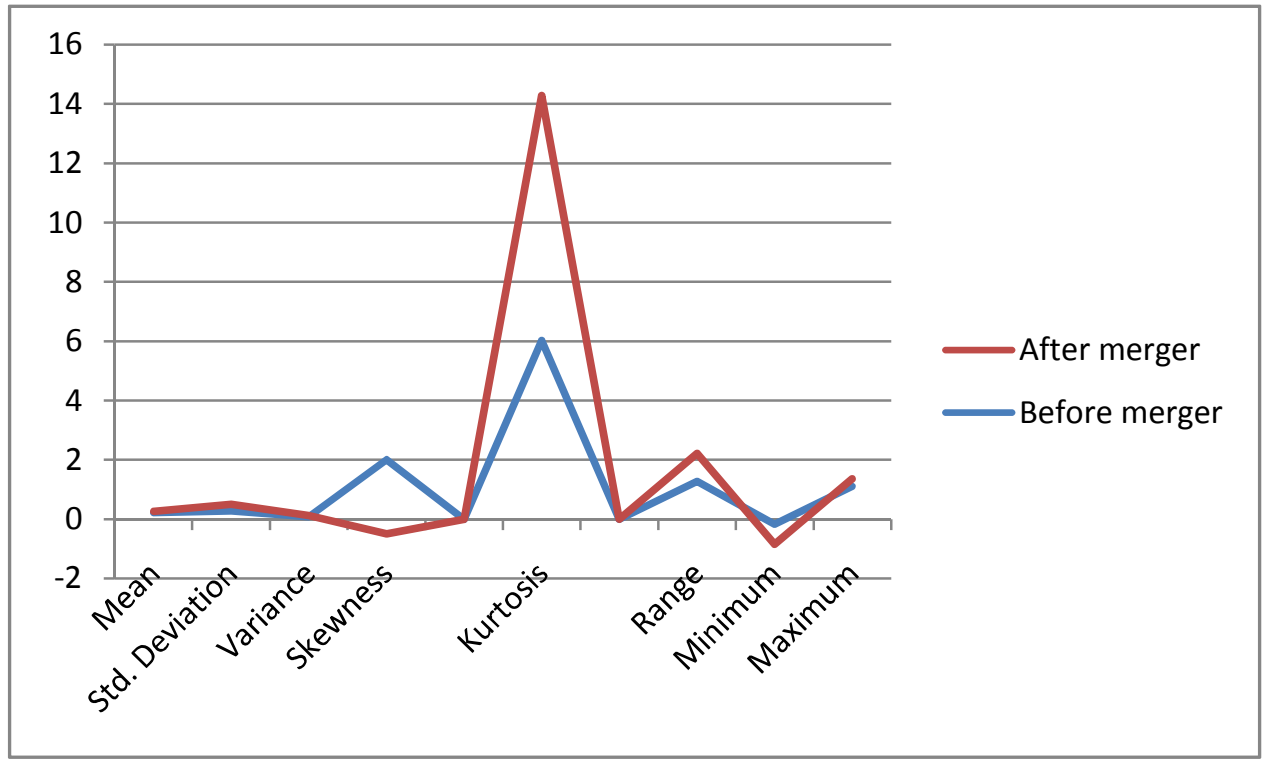

Figure 2: descriptive statistics for return on assets

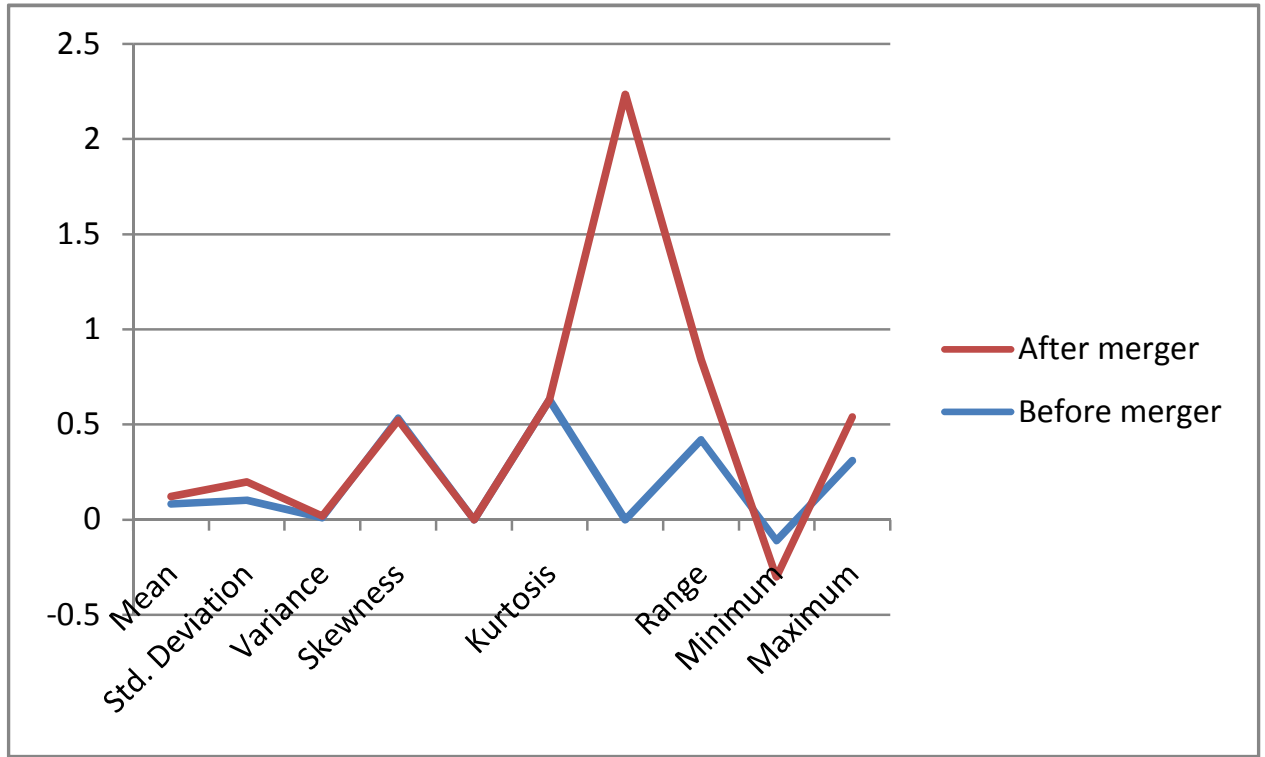


Figure 3: descriptive statistics for earnings per share

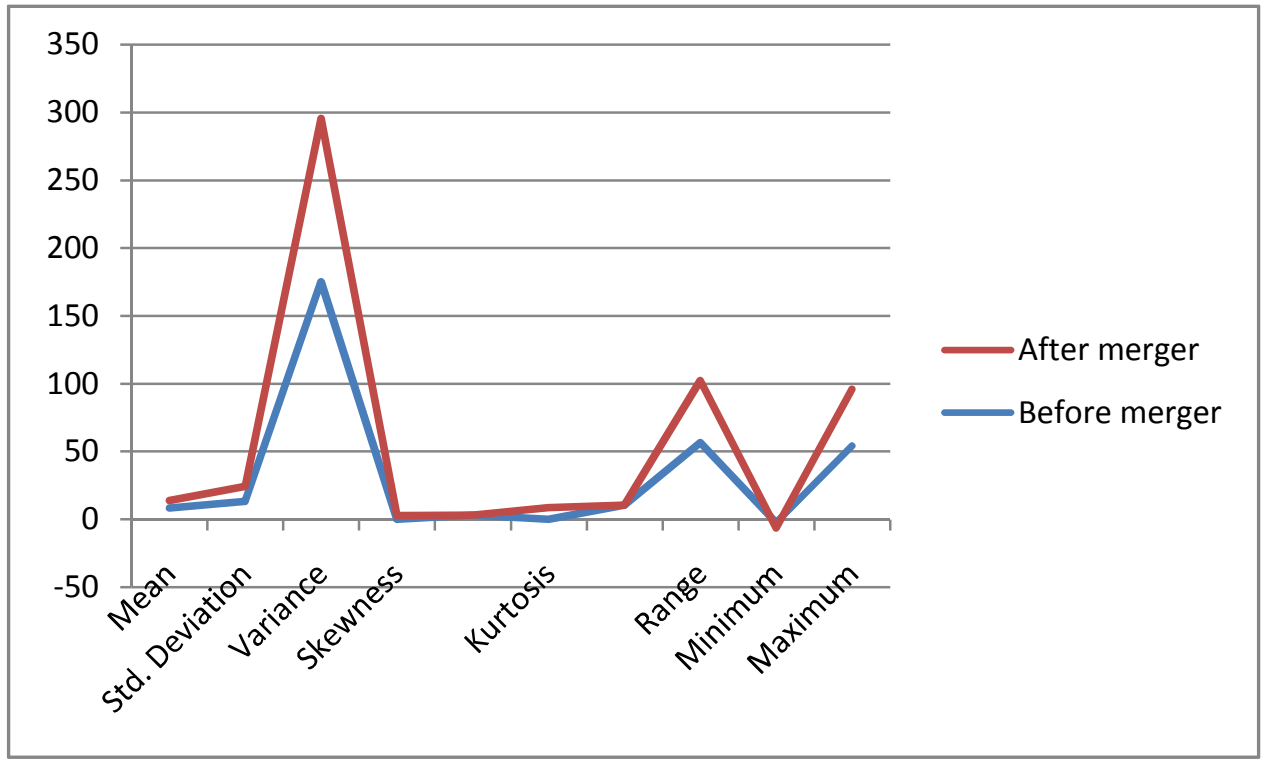

Figure 3: descriptive statistics for absolute performance using synergy realization

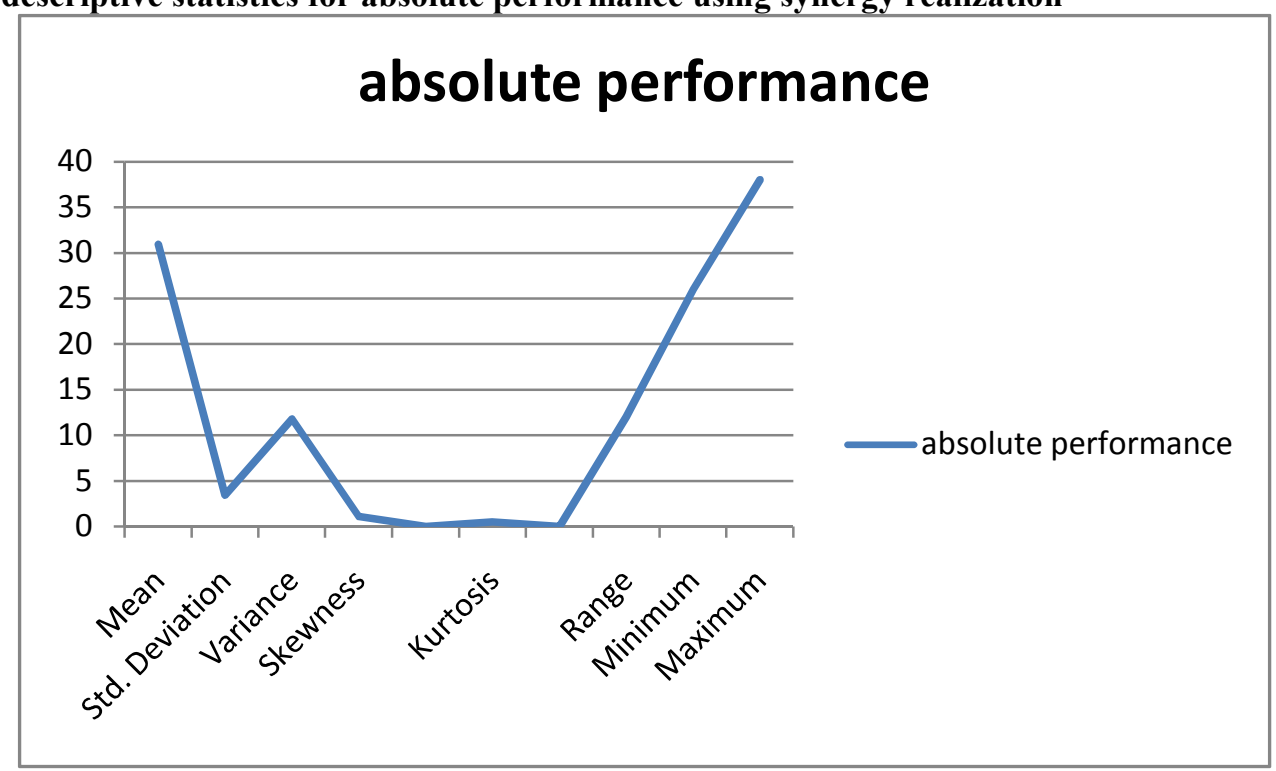

Table 3: Test of reliability for synergy realization (absolute performance)

Scale: synergy realization:

Case Processing Summary

\begin{tabular}{|cl|c|c|}
\hline & $\mathbf{N}$ & $\mathbf{\%}$ \\
\hline Cases & Valid & 114 & 100.0 \\
\hline Excluded $^{\mathrm{a}}$ & 0 & .0 \\
\hline Total & 114 & 100.0 \\
\hline
\end{tabular}

Reliability Statistics

\begin{tabular}{|r|r|r|}
\hline Cronbach's Alpha & $\begin{array}{c}\text { Cronbach's Alpha Based on } \\
\text { Standardized Items }\end{array}$ & N of Items \\
\hline .710 & .717 & 10 \\
\hline
\end{tabular}


Summary Item Statistics

\begin{tabular}{|c|r|r|r|r|r|r|r|}
\hline & \multicolumn{1}{|c|}{ Mean } & Minimum & Maximum & \multicolumn{1}{c|}{ Range } & $\begin{array}{c}\text { Maximum } \\
\text { / Minimum }\end{array}$ & Variance & N of Items \\
\hline $\begin{array}{c}\text { Item } \\
\text { Variances }\end{array}$ & .656 & .382 & .887 & .506 & 2.325 & .031 & 10 \\
\hline
\end{tabular}

\begin{tabular}{|c|c|c|c|c|c|}
\hline & $\begin{array}{l}\text { Scale } \\
\text { Mean if } \\
\text { Item } \\
\text { Deleted }\end{array}$ & $\begin{array}{l}\text { Scale } \\
\text { Variance if } \\
\text { Item } \\
\text { Deleted } \\
\end{array}$ & $\begin{array}{l}\text { Corrected } \\
\text { Item-Total } \\
\text { Correlation }\end{array}$ & $\begin{array}{c}\text { Squared } \\
\text { Multiple } \\
\text { Correlation }\end{array}$ & $\begin{array}{c}\text { Cronbach's } \\
\text { Alpha if Item } \\
\text { Deleted }\end{array}$ \\
\hline $\begin{array}{l}\text { The consolidation of input purchases } \\
\text { to reduce the purchase price/cost per } \\
\text { unit (e.g., through volume discounts). }\end{array}$ & 26.55 & 15.524 & .235 & .707 & .714 \\
\hline $\begin{array}{l}\text { The consolidation of production to } \\
\text { reduce production cost per unit (e.g., } \\
\text { through the utilization of excess } \\
\text { capacity). }\end{array}$ & 26.49 & 15.438 & .250 & . 331 & .711 \\
\hline $\begin{array}{l}\text { The consolidation of marketing to } \\
\text { reduce marketing cost per unit (e.g., } \\
\text { through an integrated sales force with } \\
\text { fewer employee. }\end{array}$ & 26.60 & 14.968 & .387 & .459 & .684 \\
\hline $\begin{array}{l}\text { The consolidation of competitors to } \\
\text { increase market power by reducing the } \\
\text { competition, thereby being able to } \\
\text { command higher prices (without losing } \\
\text { a corresponding volume) }\end{array}$ & 27.39 & 15.498 & .346 & .463 & .691 \\
\hline $\begin{array}{l}\text { The consolidation of administration to } \\
\text { reduce administrative overheads per } \\
\text { unit (e.g., through the elimination of } \\
\text { duplicated head offices). }\end{array}$ & 25.91 & 17.001 & .152 & 249 & .716 \\
\hline $\begin{array}{l}\text { The consolidation of possible suppliers } \\
\text { or consumers to reduce transaction } \\
\text { costs per unit (e.g., through the } \\
\text { elimination of intermediate storage, } \\
\text { marketing, and purchasing). }\end{array}$ & 27.34 & 15.590 & .310 & .665 & .697. \\
\hline $\begin{array}{l}\text { Access to new geographical market(s) } \\
\text { through the other firm's established } \\
\text { local sales organization to increase } \\
\text { joint sales. }\end{array}$ & 27.72 & 14.168 & .554 & .612 & .655 \\
\hline $\begin{array}{l}\text { The cross selling of complementary } \\
\text { products to joint customers to increase } \\
\text { joint sales. }\end{array}$ & 27.48 & 14.624 & .378 & .668 & .686 \\
\hline $\begin{array}{l}\text { Transfer of current know how (e.g. } \\
R \& D \text { ) from one firm to the other for } \\
\text { the latter firm to manage its operations } \\
\text { more effectively. }\end{array}$ & 27.56 & 15.381 & .445 & .522 & .678 \\
\hline $\begin{array}{l}\text { Creation of new know how from the } \\
\text { interaction between the unified firms, } \\
\text { which one of the firms can use to } \\
\text { manage its operations more } \\
\text { effectively. }\end{array}$ & 27.82 & 13.638 & .718 & .781 & .630 \\
\hline
\end{tabular}


Table 4: Results of non-financial sector:

Paired sample statistics

\begin{tabular}{|r|c|c|c|c|}
\hline & Mean & $\mathbf{N}$ & Std. Deviation & Std. Error Mean \\
\hline Pair 1 avg post roe & .0437 & 16 & .21837 & .05459 \\
\cline { 2 - 5 } avg pre roe & .2271 & 16 & .28629 & .07157 \\
\hline Pair 2 avg post roa & .0390 & 16 & .09628 & .02407 \\
\cline { 2 - 5 } avg pre roa & .0822 & 16 & .10271 & .02568 \\
\hline Pair 3 avg post eps & 5.3997 & 16 & 10.97439 & 2.74360 \\
\cline { 2 - 5 } avg pre eps & 8.4103 & 16 & 13.23085 & 3.30771 \\
\hline
\end{tabular}

Paired sample correlation

\begin{tabular}{|l|c|c|c|}
\hline & $\mathbf{N}$ & Correlation & Sig. \\
\hline Pair 1 avg post roe \& avg pre roe & 16 & .415 & .110 \\
\hline Pair 2 avg post roa \& avg pre roa & 16 & .742 & .001 \\
\hline Pair 3 avg post eps \& avg pre eps & 16 & .275 & .302 \\
\hline
\end{tabular}

Paired sample tests

\begin{tabular}{|r|c|c|c|c|c|c|c|c|}
\hline & Mean & $\begin{array}{c}\text { Std. } \\
\text { Deviation }\end{array}$ & $\begin{array}{c}\text { Std. Error } \\
\text { Mean }\end{array}$ & \multicolumn{2}{|c|}{$\begin{array}{c}\text { 95\% confidence interval of } \\
\text { the difference } \\
\text { Lower }\end{array}$} & T & df & $\begin{array}{c}\text { Sig. (2- } \\
\text { tailed) }\end{array}$ \\
\hline $\begin{array}{r}\text { Pair 1 avg } \\
\text { post roe - avg } \\
\text { pre roe }\end{array}$ & -.18340 & .27895 & .06974 & -.33204 & -.03476 & - & 15 & $.019 * *$ \\
\hline $\begin{array}{r}\text { Pair 2 avg } \\
\text { post roa - avg } \\
\text { pre roa }\end{array}$ & -.04319 & .07165 & .01791 & -.08137 & -.00501 & - & 15 & $.029 * *$ \\
\hline $\begin{array}{r}\text { Pair 3 avg } \\
\text { post eps - avg } \\
\text { pre eps }\end{array}$ & 3.01062 & 14.68062 & 3.67015 & -10.83337 & 4.81212 & -.820 & 15 & .425 \\
\hline
\end{tabular}

*Significant at 1\%. **Significant at 5\%. ***Significant at $10 \%$.

Table 5: Results of textile sector:

Paired sample statistics

\begin{tabular}{|r|c|c|c|c|}
\hline & Mean & $\mathbf{N}$ & Std. Deviation & Std. Error Mean \\
\hline Pair 1 avg post roe & .0662 & 8 & .08102 & .02865 \\
\cline { 2 - 5 } avg pre roe & .1985 & 8 & .09489 & .03355 \\
\hline Pair 2 avg post roa & .0407 & 8 & .07036 & .02487 \\
\cline { 2 - 5 } avg pre roa & .0991 & 8 & .09848 & .03482 \\
\hline Pair 3 avg post eps & 2.9419 & 8 & 6.15677 & 2.17675 \\
\cline { 2 - 5 } avg pre eps & 5.2356 & 8 & 4.17542 & 1.47623 \\
\hline
\end{tabular}

Paired sample correlations

\begin{tabular}{|l|c|c|c|}
\hline & $\mathbf{N}$ & Correlation & Sig. \\
\hline Pair 1 avg post roe \& avg pre roe & 8 & .171 & .686 \\
\hline Pair 2 avg post roa \& avg pre roa & 8 & .798 & .018 \\
\hline Pair 3 avg post eps \& avg pre eps & 8 & .226 & .591 \\
\hline
\end{tabular}

Paired sample tests

\begin{tabular}{|c|c|c|c|c|c|c|c|c|}
\hline & Mean & $\begin{array}{c}\text { Std. } \\
\text { Deviation }\end{array}$ & $\begin{array}{c}\text { Std. Error } \\
\text { Mean }\end{array}$ & $\begin{array}{l}\text { 95\% confic } \\
\text { the } \\
\text { Lower }\end{array}$ & $\begin{array}{l}\text { interval of } \\
\text { nce } \\
\text { upper }\end{array}$ & $\mathbf{T}$ & df & $\begin{array}{l}\text { Sig. (2- } \\
\text { tailed) }\end{array}$ \\
\hline $\begin{array}{l}\text { Pair } 1 \text { avg post } \\
\text { roe - avg pre roe }\end{array}$ & -.13224 & .11377 & .04022 & -.22736 & -.03713 & $3 . \overline{288}$ & 7 & $.013 * *$ \\
\hline $\begin{array}{l}\text { Pair } 2 \text { avg post } \\
\text { roa - avg pre roa }\end{array}$ & -.05837 & .05994 & .02119 & -.10848 & -.00826 & $\begin{array}{c}- \\
2.754\end{array}$ & 7 & $.028 * *$ \\
\hline $\begin{array}{r}\text { Pair } 3 \text { avg post } \\
\text { eps - avg pre eps }\end{array}$ & $\begin{array}{c}- \\
2.29375 \\
\end{array}$ & 6.61372 & 2.33830 & -7.82296 & 3.23546 & -.981 & 7 & .359 \\
\hline
\end{tabular}

*Significant at 1\%. **Significant at 5\%. ***Significant at $10 \%$. 
Table 6: Results of cement sector:

\begin{tabular}{|r|c|c|c|c|}
\multicolumn{5}{c|}{ Paired sample statistics } \\
\hline & Mean & $\mathbf{N}$ & Std. Deviation & Std. Error Mean \\
\hline Pair 1 avg post roe & -.2539 & 3 & .36474 & .21058 \\
\cline { 2 - 5 } avg pre roe & -.0497 & 3 & .15348 & .08861 \\
\hline Pair 2 avg post roa & -.0742 & 3 & .10158 & .05865 \\
\cline { 2 - 5 } avg pre roa & -.0342 & 3 & .07259 & .04191 \\
\hline Pair 3 avg post eps & -1.0617 & 3 & .46004 & .26560 \\
\cline { 2 - 5 } avg pre eps & -.6533 & 3 & 2.37593 & 1.37174 \\
\hline
\end{tabular}

\section{Paired sample correlations}

\begin{tabular}{|c|c|c|c|}
\hline & $\mathbf{N}$ & Correlation & Sig. \\
\hline Pair 1 avg post roe \& avg pre roe & 3 & .671 & .532 \\
\hline Pair 2 avg post roa \& avg pre roa & 3 & .820 & .388 \\
\hline Pair 3 avg post eps \& avg pre eps & 3 & -.735 & .474 \\
\hline
\end{tabular}

Paired sample tests

\begin{tabular}{|r|c|c|c|c|c|c|c|c|}
\hline & Mean & $\begin{array}{c}\text { Std. } \\
\text { Deviation }\end{array}$ & $\begin{array}{c}\text { Std. Error } \\
\text { Mean }\end{array}$ & \multicolumn{2}{|c|}{$\begin{array}{c}\text { 95\% confidence interval of } \\
\text { the difference } \\
\text { upper }\end{array}$} & T & df & $\begin{array}{c}\text { Sig. (2- } \\
\text { tailed) }\end{array}$ \\
\hline $\begin{array}{r}\text { Pair 1 avg post } \\
\text { roe - avg pre roe }\end{array}$ & -20418 & .28544 & .16480 & -.91327 & .50490 & - & 2 & .341 \\
\hline $\begin{array}{r}\text { Pair 2 avg post } \\
\text { roa - avg pre roa }\end{array}$ & -03993 & .05912 & .03413 & -.18680 & .10693 & - & 2 & .363 \\
\hline $\begin{array}{r}\text { Pair 3 avg post } \\
\text { eps - avg pre eps }\end{array}$ & -.40833 & 2.73193 & 1.57728 & -7.19482 & 6.37815 & -.259 & 2 & .820 \\
\hline
\end{tabular}

*Significant at 1\%. **Significant at 5\%. ***Significant at $10 \%$.

Table 7: Results of pharmaceutical companies:

Paired sample statistics

\begin{tabular}{|r|c|c|r|r|}
\hline & Mean & $\mathrm{N}$ & Std. Deviation & Std. Error Mean \\
\hline Pair 1 avg post roe & .2382 & 2 & .00877 & .00620 \\
\cline { 2 - 5 } avg pre roe & .1811 & 2 & .01672 & .01183 \\
\hline Pair 2 avg post roa & .1684 & 2 & .09199 & .06505 \\
\cline { 2 - 5 } avg pre roa & .1331 & 2 & .06795 & .04805 \\
\hline Pair 3 avg post eps & 4.5575 & 2 & 3.87848 & 2.74250 \\
\cline { 2 - 5 } avg pre eps & 8.6100 & 2 & .48083 & .34000 \\
\hline
\end{tabular}

Paired sample correlations

\begin{tabular}{|l|r|r|c|}
\hline & $\mathbf{N}$ & Correlation & Sig. \\
\hline Pair 1 avg post roe \& avg pre roe & 2 & 1.000 & .000 \\
\hline Pair 2 avg post roa \& avg pre roa & 2 & 1.000 & .000 \\
\hline Pair 3 avg post eps \& avg pre eps & 2 & 1.000 & .000 \\
\hline
\end{tabular}

Paired sample tests

\begin{tabular}{|c|c|c|c|c|c|c|c|c|}
\hline & Mean & $\begin{array}{c}\text { Std. } \\
\text { Deviation }\end{array}$ & $\begin{array}{l}\text { Std. } \\
\text { Error } \\
\text { Mean }\end{array}$ & 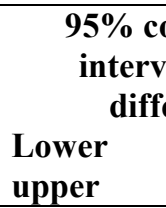 & $\begin{array}{l}\text { idence } \\
\text { of the } \\
\text { nce }\end{array}$ & $\mathbf{T}$ & df & $\begin{array}{l}\text { Sig. (2- } \\
\text { tailed) }\end{array}$ \\
\hline $\begin{array}{r}\text { Pair } 1 \text { avg post roe - } \\
\text { avg pre roe }\end{array}$ & .05708 & .00795 & .00563 & -.01440 & .12855 & 10.147 & 1 & .063 \\
\hline $\begin{array}{r}\text { Pair } 2 \text { avg post roa - } \\
\text { avg pre roa }\end{array}$ & .03525 & .02404 & .01700 & -.18076 & .25126 & 2.074 & 1 & .286 \\
\hline $\begin{array}{r}\text { Pair } 3 \text { avg post eps - } \\
\text { avg pre eps }\end{array}$ & 4.05250 & 3.39765 & 2.40250 & -34.57916 & 26.47416 & -1.687 & 1 & .341 \\
\hline
\end{tabular}

\section{References}

Andre, P., Kooli, M., \& L'her, J. F. (2004). The long-run performance of mergers and acquisitions: Evidence from the Canadian stock market. Financial management, 27-43. 
Babu, G. R. (2005). Financial Services in India: Concept Publishing Company.

Badreldin, A., \& Kalhoefer, C. (2009). The effect of mergers and acquisitions on bank performance in Egypt. Working Papers.

Chen, C., \& Findlay, C. (2003). A Review of Cross - border Mergers and Acquisitions in APEC. Asian - Pacific Economic Literature, 17(2), 14-38.

Coyle, B. (2000). Mergers and acquisitions: Global Professional Publishing.

Demsetz, R. S., \& Strahan, P. E. (1997). Diversification, size, and risk at bank holding companies. Journal of Money, Credit, and Banking, 300-313.

Gaughan, P. A. (2010). Mergers, acquisitions, and corporate restructurings: Wiley.

Gorton, G., \& Rosen, R. (1997). Strategic mergers for survival in banking. Unpublished working paper.

Green, M. B. (1990). Mergers and acquisitions: geographical and spatial perspectives: Routledge London.

Hyde, C. E. (2002). Evaluating mergers in the Australian petroleum industry. Economic Record, 78(242), 299311.

Ikeda, K., \& Doi, N. (1983). The performances of merging firms in Japanese manufacturing industry: 1964-75. The Journal of Industrial Economics, 31(3), 257-266.

irshad, m. (2005). introduction to business. pakistan: naveed pubications.

Jaffe, J., \& Randolph Westerfield, R. (2004). Corporate Finance: Tata McGraw-Hill Education.

Jarillo, J. C. (2003). Strategic logic: Palgrave Macmillan.

Kemal, M. U. (2011). Post-Merger Profitability: A Case of Royal Bank of Scotland (RBS). International Journal of Business and Social Science, 2(5), 157-162.

Kouser, R., \& Saba, I. (2011). Effects of Business Combination on Financial Performance: Evidence From Pakistan's Banking Sector. Australian Journal of Business and Management Research Vol, 1(8), 54-64.

Kumar, S., \& Bansal, L. K. (2008). The impact of mergers and acquisitions on corporate performance in India. Management Decision, 46(10), 1531-1543.

Lipczynski, J., \& Wilson, J. (2004). The economics of business strategy: Financial Times/Prentice Hall.

Mahmood, I., Aamir, M., Hussain, C. M., \& Sohail, N. (2012). Impact of Merger/Acquisition on Share Price-A Case Study of Pakistan. European Journal of Scientific Research, 67(4), 617-624.

Mishra, P., \& Chandra, T. (2010). Mergers, Acquisitions and Firm's Performance: Experience of Indian Pharmaceutical Industry. Eurasian Journal of Business and Economics, 3(5), 111-126.

Morck, R., Shleifer, A., \& Vishny, R. W. (2012). Do managerial objectives drive bad acquisitions? The Journal of Finance, 45(1), 31-48.

Raghavendra Rau, P., \& Vermaelen, T. (1998). Glamour, value and the post-acquisition performance of acquiring firms. Journal of financial economics, 49(2), 223-253.

Ravenscraft, D. J., \& Scherer, F. M. (1987). Mergers. Sell-offs, and Economic Efficiency (Brookings Institution, Washington, DC).

Rhoades, S. A. (1993). Efficiency effects of horizontal (in-market) bank mergers. Journal of Banking \& Finance, 17(2-3), 411-422.

Sharma, D. S., \& Ho, J. (2002). The impact of acquisitions on operating performance: Some Australian evidence. Journal of Business Finance \& Accounting, 29(1 - 2), 155-200.

Sudarsanam, P. S. (2003). Creating value from mergers and acquisitions: the challenges: an integrated and international perspective: Prentice Hall.

Sufian, F. (2004). The efficiency effects of bank mergers and acquisitions in a developing economy: Evidence from Malaysia. International Journal of Applied Econometrics and Quantitative Studies, 1(4), 53-74.

Tse, T., \& Soufani, K. (2001). Wealth effects of takeovers in merger activity eras: Empirical evidence from the UK. International Journal of the Economics of Business, 8(3), 365-377.

Usman, A., Khan, M. K., Wajid, A., \& Malik, M. I. Investigating the Operating Performance of Merged Companies in Textile Sector of Pakistan.

Walkling, R. A. (1985). Predicting tender offer success: A logistic analysis. Journal of Financial and Quantitative Analysis, 20(04), 461-478.

Weston, J. F., Mitchell, M., \& Mulherin, J. H. (2004). Takeovers, restructuring, and corporate governance: Prentice Hall.

Yeh, T., \& Hoshino, Y. (2000). The effects of mergers and acquisitions on Taiwanese corporations. Review of Pacific Basin Financial Markets and Policies, 3(2), 183-199.

Yook, K. C. (2004). The measurement of post-acquisition performance using EVA. Quarterly Journal of Business and Economics, 67-83. 
Appendices: Questionnaire on measurement of absolute performance of acquiring companies following merger using synergy realization

This study is designed to produce a better understanding of the extent to which the acquiring company achieved absolute performance as a result of merger $\&$ acquisition. The findings are intended to support companies in their future strategic decisions.

Please answer this questionnaire in respect of a specific strategic Merger project.

\begin{tabular}{|c|c|}
\hline Synergy realization: & Very low \\
Please estimate the degree to which the M\&A realized the following \\
benefits:
\end{tabular}

B) personal information (confidential, for classification purpose only)

What is your current position?

How long have you worked for this company?

\begin{tabular}{|l|l|l} 
Please encircle the most appropriate: & Not At All Very much
\end{tabular}

How involved are you in strategic activities of your company?

How involved are you in organizational activities of your company?

How involved are you in financial activities of your company?

Thanks a lot for your contribution!!

Khurram Ashfaq

Lecturer at Government College University Faisalabad, Pakistan 
The IISTE is a pioneer in the Open-Access hosting service and academic event management. The aim of the firm is Accelerating Global Knowledge Sharing.

More information about the firm can be found on the homepage:

http://www.iiste.org

\section{CALL FOR JOURNAL PAPERS}

There are more than 30 peer-reviewed academic journals hosted under the hosting platform.

Prospective authors of journals can find the submission instruction on the following page: http://www.iiste.org/journals/ All the journals articles are available online to the readers all over the world without financial, legal, or technical barriers other than those inseparable from gaining access to the internet itself. Paper version of the journals is also available upon request of readers and authors.

\section{MORE RESOURCES}

Book publication information: http://www.iiste.org/book/

\section{IISTE Knowledge Sharing Partners}

EBSCO, Index Copernicus, Ulrich's Periodicals Directory, JournalTOCS, PKP Open Archives Harvester, Bielefeld Academic Search Engine, Elektronische Zeitschriftenbibliothek EZB, Open J-Gate, OCLC WorldCat, Universe Digtial Library, NewJour, Google Scholar

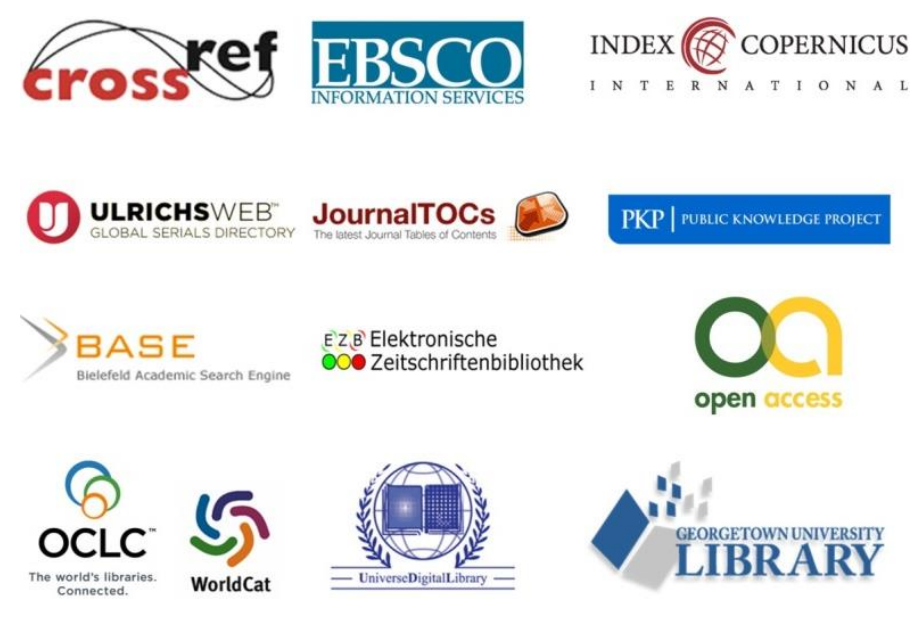

